\title{
KEDUDUKAN KETETAPAN MPR BERDASARKAN UU NO. 12 TAHUN 2011 TENTANG PEMBENTUKAN PERATURAN PERUNDANG-UNDANGAN*
}

\author{
Delfina Gusman dan Andi Nova \\ Fakultas Hukum Universitas Andalas \\ E-mail : Vivin_Nissa@yahoo.co.id
}

\begin{abstract}
MPR Decree in resettlement of legislation under the Constitution of 1945 on the basis of Law No. 12 Year 2011 cocerning formation of legislation gives rise to a variety of polemics in the position of the MPR as State institutions. Provisions of the MPR is considered to have urgency in Indonesia's system, because the MPR as State institutions is considered to still have the duty and the authority of its strategic, e.g: inauguration of President and Vice President, the establishment of the Constitution. MPR also made provisions as one of basic national legislation program.
\end{abstract}

Keywords: MPR Decree, national legislation program, rule of Iaw

\begin{abstract}
Abstrak
Tap MPR di bawah UUD 1945 sebagai dasar pembentukan Undang-Undang Nomor 12 dari 2011 tentang pembentukan peraturan perundang-undangan menimbulkan berbagai polemik terhadap posisi MPR sebagai lembaga negara. Keberadaan dari MPR masih dianggap memiliki urgensi dalam sistem di Indonesia, karena MPR sebagai lembaga negara yang dianggap masih memiliki tugas dan kewenangan yang strategis, misalnya: pelantikan Presiden dan Wakil Presiden, pembentukan konstitusi. MPR juga membuat ketetapan sebagai salah satu program legislasi dasar nasional.
\end{abstract}

Kata kunci: Keputusan MPR, program legislasi nasional, rule of law

\section{Pendahuluan}

Indonesia adalah negara hukum. Gagasan negara hukum dibangun dengan mengembangkan perangkat hukum itu sendiri sebagai suatu sistem yang fungsional dan berkeadilan, dikembangkan dengan menata supra struktur dan infra struktur kelembagaan politik, ekonomi dan sosial yang tertib dan teratur, serta dibina dengan membangun budaya dan kesadaran hukum yang rasional dan impersonal dalam kehidupan bermasyarakat, berbangsa dan bernegara. Untuk itu, sistem hukum perlu dibangun (law making) dan ditegakkan (law enforcing) sebagaimana mestinya, dimulai dengan konstitusi sebagai hukum yang paling tinggi kedudukannya. ${ }^{1}$

\footnotetext{
- Artikel ini merupakan artikel hasil penelitian dengan sumber Dana DIPA Fakultas Hukum Universitas Andalas Tahun 2011, dengan Nomor Kontrak Penelitian 03/ XIII/ D/ FHuk/ 2011
}

Perubahan Keempat UUD 1945 pada 2002, konsepsi negara hukum atau "Rechtsstaat" yang sebelumnya hanya tercantum dalam Penjelasan UUD 1945, dirumuskan dengan tegas dalam Pasal 1 ayat (3) yang menyatakan, "Negara Indonesia adalah negara hukum." Dalam konsep negara hukum itu, diidealkan bahwa yang harus dijadikan panglima dalam dinamika kehidupan kenegaraan adalah hukum, bukan politik ataupun ekonomi. Oleh karena itu, jargon yang biasa digunakan dalam bahasa Inggris untuk menyebut prinsip negara hukum adalah 'the rule of law, not of man'. Pemerintahan pada pokoknya adalah hukum sebagai sistem, bukan orang perorang yang hanya bertindak sebagai 'wayang' dari skenario sistem yang mengaturnya. ${ }^{2}$

Jimly Asshiddiqie, Gagasan Negara Hukum Indonesia, http:/ / jimly.com/ makalah/ namafile/ 57/ Konsep_Negar a_Hukum_Ind $127 \mathrm{k}, \mathrm{hlm} .1$

2 Ibid. 
Pada 17 Agustus 1945 Negara Indonesia lahir sebagai suatu negara baru di tengah-tengah masyarakat negara-negara di dunia. Kecuali pengumuman tentang bentuk negara, yaitu republik, Indonesia juga menyatakan diri sebagai negara berdasar hukum (negara hukum). Lebih dari setengah abad kemudian, negara Republik Indonesia masih harus bergulat dengan berbagai masalah mendasar yang timbul sebagai akibatnya. Eksistensi Republik Indonesia sebagai negara kesatuan ternyata masih harus terus dibina dan dipertahankan. Selain itu, pembangunan negara hukum ternyata belum juga kunjung selesai dengan baik, bahkan yang terjadi adalah sebaliknya. Indonesia menjadi terkenal di dunia sebagai negara dengan sistem hukum sangat buruk. Dimaksud dengan pembangunan yang belum kunjung selesai adalah bagaimana menjadikan negara hukum itu suatu organisasi yang secara substansial mampu menjadi rumah yang menyenangkan, menyejahterakan dan membahagiakan bagi bangsa Indonesia.

Konsep negara hukum Indonesia, Simorangkir memberikan pengertian, bahwa negara termasuk pemerintah dan lembaga-lembaga negara lain dalam menjalankan aktifitasnya harus dilandasi oleh hukum dan dapat dipertanggungjawabkan secara hukum. Hukum disini adalah dalam arti luas, tidak semata-mata undang-undang termasuk didalamnya hukum hukum tidak tertulis. Negara hukum Indonesia bukanlah konsep negara hukum dalam pengertian hukum formal, melainkan negara hukum dalam arti materil, yang didalamnya tercakup pengertian bahwa negara tidak hanya melindungi segenap bangsa Indonesia, tetapi juga memiliki kewaj iban untuk memajukan kesejahteraan umum dan mencerdaskan kehidupan bangsa. ${ }^{3}$

Negara Indonesia juga merupakan negara demokrasi, dimana bentuk sistem penyelenggaraan negaranya adalah perwujudan kedaulatan rakyat. Perbedaannya dengan sistem lain terletak pada siapa pelaksana kedaulatan tersebut

Wahyudi Djafar, "Menegaskan Kembali Komitmen Negara Hukum : Sebuah Catatan Atas Kecenderungan Defisit Negara Hukum di Indonesia", Jurnal Konstitusi Vol. 7 No. 5 Oktober 2010, Padang: Fak. Hukum Univ. Andalas Padang, hlm. 164 dan bagaimana melaksanakannya. Hal ini dikarenakan dalam negara modern adalah utopia jika mengharapkan rakyat melaksanakan sendiri seluruh kedaulatan yang dimilikinya. ${ }^{4}$

Pasca perubahan UUD 1945, maka ada 6 (enam) lembaga negara yang diberikan kekuasaan secara langsung oleh konstitusi. UndangUndang Dasar merupakan hukum tertinggi di mana kedaulatan berada di tangan rakyat dan dijalankan sepenuhnya menurut UUD. UUD memberikan pembagian kekuasaan (separation of power) kepada 6 Lembaga Negara dengan kedudukan yang sama dan sejajar, yaitu Presiden, Majelis Permusyawaratan Rakyat (MPR), Dewan Perwakilan Rakyat (DPR), Dewan Perwakilan Daerah (DPD), Badan Pemeriksa Keuangan (BPK), Mahkamah Agung (MA), dan Mahkamah Konstitusi (MK). ${ }^{5}$

Bab I Pasal 1 Ayat (2) UUD 1945 menentukan bahwa kedaulatan berada di tangan rakyat dan dilaksanakan menurut Undang-Undang Dasar. Dengan rumusan itu dimaksudkan, bahwa kedaulatan itu pada hakekatnya tetap melekat dan berada di tangan rakyat, dan Undang-Undang Dasar yang mengatur pelaksanaannya. Sebagian kedaulatan itu tetap dipegang dan dilaksanakan sendiri oleh rakyat, yaitu dalam hal memilih Presiden dan Wakil Presiden, memilih anggota Dewan Perwakilan Rakyat, anggota Dewan Perwakilan Rakyat Daerah, dan anggota Dewan Perwakilan Daerah. Berdasarkan ketentuan undang-undang dasar itu, undangundang kemudian juga menetapkan, rakyat tetap memegang kedaulatannya secara langsung, yaitu dalam hal memilih Gubernur dan Wakil Gubernur, memilih Bupati dan Wakil Bupati, serta Walikota dan Wakil Walikota. Untuk selebihnya undang-undang dasar menetapkan dibentuknya lembaga-lembaga negara (DPR, MPR, DPD, Presiden dan Wakil Presiden, Badan Pe-

\footnotetext{
4 Yordan Gunawan dan Alex Adi Iskandar, "Implementasi Kedaulatan Rakyat Dalam Sistem Ketatanegaraan Pasca Amandemen UUD 1945", J urnal Konstitusi Vol. 3 No. 1 J uni 2010, Padang: Fak. Hukum Univ. Andalas Padang, hlm. 64

5 Delfina Gusman, "Politik Hukum dan Modifikasi Hukum Dalam Pembentukan Peraturan Perundang-undangan Nasional", J urnal IImiah TAMBUA, Vol. X No. 1 J anuariApril 2011, Univ. Mahaputra Muhammad Yamin Solok, hlm. 76
} 
meriksa Keuangan, Mahkamah Agung, dan Mahkamah Konstitusi), dan kepada masing-masing lembaga itu ditetapkan secara definitif fungsi dan kewenangannya sesuai dengan posisi/ kedudukannya. Lembaga-lembaga negara itu berada dalam kedudukan yang setara. Antara lembaga yang satu dengan yang lain dilaksanakan prinsip saling mengawasi dan saling mengimbangi atau checks and balances. ${ }^{6}$

Berdasarkan ketentuan Pasal 7 Ayat (1) Undang-Undang Nomor 12 Tahun 2011 Tentang Pembentukan Peraturan Perundang-undangan, TAP MPR kembali masuk dalam jenis peraturan perundang-undangan di Indonesia. Pada pasal itu, jenis dan hierarki peraturan perundangundangan mulai dari yang tertinggi secara berturut-turut adalah UUD 1945, TAP MPR, UU/ Peraturan Pemerintah Pengganti UU, Peraturan Pemerintah, Peraturan Presiden, Peraturan Daerah Provinsi, Peraturan Daerah Kabupaten/ Kota. Seperti diketahui, sebelumnya TAP MPR pernah masuk ke dalam hierarki peraturan perundang-undangan sebagaimana diatur dalam TAP MPRS No. XX Tahun 1966 dan TAP MPR No III Tahun 2000. Namun, karena adanya perubahan kewenangan MPR dalam amendemen UUD 1945, akhirnya TAP MPR dikeluarkan dari hierarki dengan berlakunya UU Nomor 10 Tahun 2004 tentang Pembentukan Peraturan Perundang-Undangan. Di dalam undang-undang itu, UU/Perppu langsung berada di bawah UUD 1945.

Kedudukan TAP MPR penting artinya untuk diteliti, karena beberapa peraturan yang menjadikan TAP MPR sebagai salah satu jenis peraturan perundang-undangan bertolak belakang dengan pendapat A. Hamid Attamimi yang menyatakan bahwa UUD 1945 dan TAP MPR tidak termasuk jenis peraturan perundang-undangan, melainkan sebagai aturan dasar/pokok negara, sedangkan yang termasuk peraturan perundang-undangan adalah: undang-undang/ perpu, peraturan pemerintah, keputusan presiden, keputusan menteri, keputusan kepala lem-

\footnotetext{
Delfina Gusman, "Independensi Bank Indonesia Sebagai Bank Sentral Dalam Sistem Ketatanegaraan Indonesia", J urnal Normative, Vol. 2 No. 1 J uni 2010, Padang: Universitas Taman Siswa Padang, hlm. 5
}

baga pemerintah non departemen, keputusan direktur jenderal departemen, keputusan kepala badan negara di luar jajaran pemerintah yang dibentuk dengan undang-undang, peraturan daerah tingkat I, Keputusan Gubernur kepala daerah tingkat II, Keputusan Bupati/ Wali Kotamadya Kepala Daerah Tingkat II. ${ }^{7}$ Lain lagi halnya dengan pendapat Jimly Assiddiqie yang menyebutkan bahwa kedudukan Ketetapan MPR sejak lama mendapat kritik dari para ahli hukum tata negara.

Penelitian terhadap kedudukan TAP MPR akan mampu memberikan jawaban akademis karena ada yang menyatakan bahwa masuknya TAP MPR ke dalam hierarki merupakan langkah mundur. Ini seperti mundur kembali ke belakang. Padahal, dahulu TAP MPR sudah dikeluarkan dari hierarki.

\section{Permasalahan}

Berdasarkan latar belakang masalah di atas, dapat dirumuskan suatu masalah yaitu bagaimana kedudukan Ketetapan Majelis Permusyawaratan Rakyat berdasarkan Undang-Undang Nomor 12 Tahun 2011 Tentang Pembentukan Peraturan Perundang-Undangan?

\section{Metode Penelitian}

Penelitian ini merupakan penelitian hukum normatif (yuridis normatif), yaitu beranjak dari norma-norma hukum. Pendekatan yang digunakan adalah pendekatan analisis hukum (analythical approach). Dalam pendekatan ini, peneliti menelaah dan mengkaji secara mendalam atas bunyi teks sebuah peraturan perundang-undangan. Sumber data adalah data sekunder, yaitu data yang tidak langsung diperoleh dari lapangan, melainkan diperoleh dari tangan kedua. Data sekunder dalam penelitian ini dapat dikategorikan kepada bahan hukum primer, bahan hukum sekunder, dan bahan hukum tertier. Bahan hukum primer dalam pene-

\footnotetext{
A. Hamid Attamimi, 1990, Peranan Keputusan Presiden Republik Indonesia dalam Penyelenggaraan Pemerintahan Negara; Suatu Studi Analisis Mengenai Keputusan Presiden yang Berfungsi Pengaturan dalam kurun waktu Pelita I - Pelita IV, Disertasi untuk memperoleh Gelar Doktor dalam IImu Hukum pada Fakultas Pascasarjana Universitas Indonesia, J akarta, hlm. 289.
} 
litian ini adalah seluruh peraturan yang berkaitan dengan ketetapan MPR terutama sekali Undang-Undang Nomor 12 Tahun 2011 Tentang Pembentukan Peraturan Perundang-undangan. Bahan hukum sekunder berupa buku-buku yang berkaitan dengan obj ek penelitian.

Data yang sudah dikumpulkan diolah. Selanjutnya data yang telah selesai diseleksi diatur agar memudahkan untuk pengolahan seIanjutnya. Data yang terkumpul dianalisis dengan menggunakan teknik analisis kualitatif. Teknik analisis kualitatif yang dengan cara deskriptif analitis, yaitu dengan memberikan gambaran yang memadai terhadap seluruh persoalan penelitian, kemudian gambaran yang telah dipaparkan demikian rupa dianalisis. Dalam hal ini dimaksudkan sebagai analisis data penelitian dengan menggunakan kerangka teoritis dan konseptual yang telah dijabarkan sebelumnya. Selanjutnya, hasil analisis ditempatkan sesuai klasifikasi data sehingga data yang ada tersusun secara sistematis. Penempatan hasil analisis merupakan salah satu proses dan rangkaian dari penelitian yang dilaksanakan sehingga data betul-betul teruj $\mathrm{j}$ validitasnya dan menutup peluang terjadinya bias. Tentunya melalui analisis yang dilaksanakan yang dituju dengannya adalah terdapatnya sinkronisasi yang logis dan kronologis dalam seluruh tahapan penelitian sehingga hasil penelitian betul-betul mampu menjawab seluruh permasalahan penelitian. Dengannya, penelitian ini diarahkan untuk betul-betul mampu merealisasikan tujuan dan manfaat yang telah dirancang sebelumnya yang akhirnya betul-betul mampu memberikan kesimpulan yang representatif.

\section{Pembahasan}

Sistem perundang-undangan suatu negara tidak lepas dari sistem hukum yang berlaku di suatu negara, karena peraturan perundang-undangan sebagai hukum tertulis merupakan esensi atau bagian penting dalam sistem hukum dari negara hukum yang demokratis. ${ }^{8}$ Negara

\footnotetext{
Machmud Aziz, "Pengujian Peraturan Perundang-undangan Dalam Sistem Perundang-undangan Indonesia", J urnal Konstitusi Vol. 7 No. 5 Oktober 2010, Padang: Fak. Hukum Univ. Andalas Padang, hlm. 118
}

Hukum yang demokratis meletakkan kedaulatan rakyat sebagai posisi tertinggi, kehendak rakyat adalah segala-galanya, sehingga hanya pemerintahan yang demokratik yang memberikan kesempatan sebesar-besarnya bagi warga negara untuk menggunakan kebebasan menentukan nasibnya sendiri di bawah hukum yang mereka pilih. ${ }^{9}$

Azhary, berpendapat ciri-ciri negara hukum Indonesia, sebagai berikut: ${ }^{10}$ hukumnya bersumber pada pancasila; berkedaulatan rakyat; pemerintah berdasar atas sistem konstitusi; persamaan dindalam hukum dan pemerintahan; kekuasaan kehakiman yang bebas dari pengaruh kekuasaan lainnya; pembentukan undang-undang oleh Presiden bersama DPR; dan dianutnya sistem MPR.

Pernyataan Indonesia sebagai negara hukum itu sendiri sebelum amandemen UUD 1945 ditemukan pada penjelasan UUD 1945, yang menyatakan bahwa sistem pemerintahan terdiri atas 9 kunci pokok, yakni: ${ }^{11}$ Indonesia, ialah negara yang berdasar atas hukum (Rechtstaat); sistem konstitusionil; kekuasaan negara yang tertinggi ditangan MPR; Presiden ialah penyelenggara pemerintah negara yang tertinggi di bawah MPR; Presiden tidak bertanggungjawab kepada DPR; menteri negara adalah pembantu presiden, menteri negara tidak bertanggung jawab kepada DPR; kekuasaan Kepala Negara tidak tak terbatas; kedudukan DPR adalah kuat; dan menteri-menteri negara bukan pegawai tinggi biasa

Berbeda halnya dengan setelah perubahan UUD 1945, pernyataan Indonesia sebagai negara hukum jelas diatur pada Pasal 1 ayat 3 UUD 1945, begitu juga halnya dengan keberadaan MPR yang bukan lagi sebagai pemegang

\footnotetext{
9 Veri J unaidi, “Pelanggaran Sistematis, Terstruktur dan Masif: Suatu Sebab Pembatalan Kehendak Rakyat dalam Pemilihan Kepala Daerah Tahun 2010", Jurnal Konstitusi Vol. 7 No. 5 Oktober 2010, Padang: Fak. Hukum Univ. Andalas Padang, hlm. 43

10 Fatmawati, "Perlindungan Hak Atas Kebebasan Beragama dan Beribadah Dalam Negara Hukum Indonesia", Jurnal Konstitusi Vol. 8 No. 4 Agustus 2011, Padang: Fak. Hukum Univ. Andalas Padang, hlm. 501

11 R.M.A.B.Kusuma, "Sistem Pemerintahan Sebelum dan Sesudah Amandemen", J urnal Konstitusi Vol. 1 No. 1 November 2010, Padang: Fak. Hukum Univ. Andalas Padang, hIm. 13
} 
kedaulatan rakyat sebagaimana yang termaktub pada Pasal 1 ayat 2 UUD 1945 sebelum amandemen.

Keberadaan MPR sebagai lembaga negara pelaksana kedaulatan rakyat secara tidak langsung masih ada setelah perubahan UUD 1945, meskipun ada lembaga-lembaga negara lain yang menurut UUD 1945 juga sebagai pelaksana kedaulatan rakyat. Oleh karena itu pada UU No. 12 Tahun 2011, kedudukan TAP MPR ditempatkan lagi dalam hierarki peraturan perundang-undangan. Kedudukan TAP MPR dapat diketahui dengan melihat dan memahami materi muatan UU Nomor 12 Tahun 2011.

\section{TAP MPR Sebagai Salah Satu Jenis Peraturan Perundang-undangan}

Menurut stuffenbau theory (teori hirarki peraturan perundang-undangan), secara umum dapat dikelompokkan peraturan perundang-undangan ke dalan empat tingkat yaitu: pertama, adalah ketentuan yang memuat norma dasar (grundnorm) yaitu UUD; kedua adalah ketentuan legislatif yang menjabarkan norma dasar yaitu Undang Undang; ketiga adalah ketentuan yang dibentuk oleh pemerintah sebagai aturan pelaksanaan dari undang-undang yaitu Peraturan Pemerintah (implementing legislation); dan keempat adalah ketentuan organik untuk mengoperasionalkan secara rinci Peraturan Pemerintah yaitu antara lain: Peraturan Presiden, Peraturan Menteri, dan Peraturan Daerah. Dalam praktik, banyak dijumpai bahwa penyusunan peraturan perundang-undangan tidak selalu dilakukan seraca runtut, dapat saja misalnya suatu undang-undang memerintahkan penetapan peraturan pelaksanaan dari salah satu norma yang dimuatnya untuk diatur lebih lanjut dengan Peraturan Presiden, Peraturan Menteri, atau Peraturan Daerah. ${ }^{12}$

Sebagai penguat dari teori Hans Kelsen dapat dipadankan dengan teori Algemeine Rechtslehre (Hans Nawiasky). Berdasarkan teori Nawiasky ini norma hukum itu terdiri dari: per-

12 Yuliandri, 2007, Asas-Asas Pembentukan Peraturan Perundang-undangan Yang Baik Dalam Rangka Pembuatan Undang-Undang Berkelanjutan, Disertasi, Surabaya: Universitas Airlangga, hlm. 44-45 tama, Staatsfundamentalnorm (Norma Fundamental Negara); kedua, Staatsgrundgesetz (Aturan Dasar/Pokok Negara); ketiga, Formell Gesetz (UU Formal); keempat, Verordnung dan Autonome Satzung (Aturan Pelaksana dan Aturan Otonom). ${ }^{13}$

Berdasarkan teori di atas, dapat ditinjau keberadaan norma hukum di Indonesia secara historis berdasarkan peraturan yang pernah ada. Sejak tahun 1966 sampai dengan sekarang telah dilakukan perubahan atas hierarki (tata urutan) peraturan perundang-undangan di Indonesia. Pada tahun 1996, dengan Ketetapan MPR No. XX/ MPR/ 1966 Lampiran 2, disebutkan bahwa hierarki peraturan perundang-undangan Indonesia adalah: ${ }^{14}$ Undang-undang Dasar 1945; Ketetapan MPR; Undang-undang atau Peraturan Pemerintah Pengganti Undang-undang; Peraturan Pemerintah; Keputusan Presiden; Peraturanperaturan pelaksananya, seperti: Peraturan Menteri, Instruksi Menteri, dan lain-lainnya

Pada 1999, dengan dorongan yang besar dari berbagai daerah di Indonesia untuk mendapatkan otonomi yang lebih luas serta semakin kuatnya ancaman disintegrasi bangsa, pemerintah mulai mengubah konsep otonomi daerah. Maka lahirlah Undang Undang No. 22 tahun 1999 tentang Pemerintahan Daerah (telah diganti dengan UU No. 32 Tahun 2004) dan Undang-undang No. 25 tahun 1999 tentang Perimbangan Keuangan Pusat dan Daerah (telah diganti dengan UU No. 33 Tahun 2004). Perubahan ini tentu saja berimbas pada tuntutan perubahan terhadap tata urutan peraturan perundang-undangan di Indonesia. Karena itulah, dibuat Ketetapan MPR No. III/MPR/2000 Tentang Sumber Hukum dan Tata Urutan Peraturan Perundang-undangan. Kalau selama ini Peraturan Daerah (Perda) tidak dimasukkan dalam tata urutan peraturan perundang-undangan, setelah lahirnya Ketetapan MPR No. III Tahun 2000, Perda ditempatkan dalam tata urutan tersebut setelah Keputusan Presiden.

Lengkapnya, tata urutan peraturan perundang-undangan di Indonesia setelah tahun

\footnotetext{
13 Ibid.

14 Ibid, hlm. 51
} 
2000 adalah sebagai berikut: ${ }^{15}$ Undang-undang Dasar 1945; Ketetapan Majelis Permusyawaratan Rakyat; Undang-undang; Peraturan Pemerintah Pengganti Undang-undang; Peraturan Pemerintah; Keputusan Presiden; dan Peraturan Daerah

Pada 24 Mei 2004 Ialu, DPR telah menyetujui RUU Pembentukan Peraturan Perundangundangan (PPP) menjadi UU No. 10 Tahun 2004, yang berlaku efektif pada bulan November 2004. Keberadaan undang-undang ini sekaligus menggantikan pengaturan tata urutan peraturan perundang-undangan yang ada dalam Ketetapan MPR No. III Tahun 2000. Tata urutan peraturan perundang-undangan dalam UU PPP ini diatur dalam Pasal 7 sebagai berikut: Undangundang Dasar 1945; Undang-Undang/Peraturan Pemerintah Pengganti Undang-undang; Peraturan Pemerintah; Peraturan Presiden; Peraturan Daerah, yang meliputi: Peraturan Daerah Provinsi, Peraturan Daerah Kabupaten/Kota, Peraturan Desa. ${ }^{16}$

Pada UU No.10 Tahun 2004, Ketetapan MPR tidak termasuk lagi dalam tata urutan peraturan perundang-undangan di Indonesia. Namun, terjadi perubahan lagi tentang kedudukan Ketetapan MPR setelah dicabutnya UU No.10 Tahun 2004 dan digantikan dengan UU No.12 Tahun 2011 Tentang Pembentukan Peraturan Perundang-undangan. ${ }^{17}$

Kedudukan TAP MPR Sebagai Salah Satu Jenis Peraturan Perundang-undangan dapat diketahui melalui rumusan UU Nomor 12 Tahun 2011 pada Bab III Jenis, Hierarki, dan Materi Muatan Peraturan Perundang-undangan. Pasal 7 menentukan hal-hal sebagai berikut. Pertama, Jenis dan hierarki Peraturan Perundang-undangan terdiri atas: Undang-Undang Dasar Negara Republik Indonesia Tahun 1945; Ketetapan Majelis Permusyawaratan Rakyat; Undang-Undang/ Peraturan Pemerintah Pengganti UndangUndang; Peraturan Pemerintah; Peraturan Pre-

\footnotetext{
$15 \quad$ Ibid, hlm. 53

16 Delfina Gusman, "Tinjauan Materi dan Status Hukum Ketetapan MPRS/ MPR Berdasarkan Ketetapan RI Nomor I / MPR/ 2003", J urnal IImiah Normative, Univ. Taman Siswa Padang Padang, Vol. I No. 8 Oktober 2008, hlm. 21

17 Loc. cit
}

siden; Peraturan Daerah Provinsi; dan Peraturan Daerah Kabupaten/Kota. Kedua, kekuatan hukum Peraturan Perundang-undangan sesuai dengan hierarki sebagaimana dimaksud pada ayat (1). Penjelasan I. Umum disebutkan bahwa sebagai penyempurnaan terhadap Undang-undang sebelumnya, terdapat materi muatan baru yang ditambahkan dalam Undangundang ini, yaitu antara lain: penambahan Ketetapan Majelis Permusyawaratan Rakyat sebagai salah satu jenis Peraturan Perundang-undangan dan hierarkinya ditempatkan setelah UUD 1945.

\section{Kategorisasi TAP}

Apabila membaca, memahami dan menganalisis ketentuan Undang-Undang Nomor 12 Tahun 2011 dapat diketahui bahwa Ketetapan MPR terdiri dari beberapa kategori. Hal ini dapat diketahui dari rumusan Penjelasan Pasal 7 Ayat 1 huruf B yang menyatakan bahwa "Yang dimaksud dengan "Ketetapan Maj elis Permusyawaratan Rakyat" adalah Ketetapan Majelis Permusyawaratan Rakyat Sementara dan Ketetapan Majelis Permusyawaratan Rakyat yang masih berlaku sebagaimana dimaksud dalam Pasal 2 dan Pasal 4 Ketetapan Majelis Permusyawaratan Rakyat Republik Indonesia No. I/ MPR/2003 tentang Peninjauan Terhadap Materi dan Status Hukum Ketetapan Majelis Permusyawaratan Rakyat Sementara dan Ketetapan Majelis Permusyawaratan Rakyat Tahun 1960 sampai dengan Tahun 2002, tanggal 7 Agustus 2003. ${ }^{18}$

Akibat ditetapkannya Ketetapan MPR tersebut, maka seluruh Ketetapan MPRS dan Ketetapan MPR yang berjumlah 139 dikelompokkan ke dalam 6 pasal (kategori) sesuai dengan materi dan status hukumnya. Substansi Ketetapan MPR tersebut adalah sebagai berikut. ${ }^{19}$ Pertama, Kategori I: TAP MPRS/TAP MPR yang dicabut dan dinyatakan tidak berlaku (8 Ketetapan); kedua, Kategori II: TAP MPRS/TAP MPR yang dinyatakan tetap berlaku dengan ketentuan (3 Ketetapan); ketiga, Kategori III: TAP

\footnotetext{
18 Abdul Gani Abdullah, "Pengantar Memahami UndangUndang Tentang Pembentukan Peraturan Perundangundangan", J urnal legislasi Indonesia, Vol. 1 No. 2 September 2004, hlm 5

19 Ibid, hlm. 22-23
} 
MPRS/ TAP MPR yang dinyatakan tetap berlaku sampai dengan terbentuknya Pemerintahan Hasil Pemilu 2004 (8 Ketetapan); keempat, Kategori IV: TAP MPRS/ TAP MPR yang dinyatakan tetap berlaku sampai dengan terbentuknya Undang-undang (11 Ketetapan); kelima, Kategori V: TAP MPRS/TAP MPR yang dinyatakan masih berlaku sampai dengan ditetapkannya Peraturan Tata Tertib Baru oleh MPR Hasil Pemilu 2004 (5 Ketetapan); dan keenam, Kategori VI: TAP MPRS/ TAP MPR yang dinyatakan tidak perlu dilakukan tindakan hukum lebih lanjut, baik karena bersifat final (einmalig), telah dicabut, mau pun telah selesai dilaksanakan (104 Ketetapan)

Berdasarkan kategori di atas, dapat dipahami bahwa TAP MPR itu terdiri dari TAP MPRS dan TAP MPR. Namun tidak semua berlaku. Implikasinya tentu TAP MPR yang masuk dalam jenis dan hirarki peraturan perundang-undangan setelah berlakunya Undang-Undang No. 12 Tahun 2011 adalah TAP MPR yang termasuk kategori masih berlaku.

Ketetapan Majelis Permusyawaratan Rakyat Nomor I/ MPR/ 2003 tentang Peninj auan Terhadap Materi dan Status Hukum Ketetapan Majelis Permusyawaratan Rakyat Sementara dan Ketetapan Majelis Permusyawaratan Rakyat Republik Indonesia Tahun 1960 sampai dengan Tahun 2002 merupakan Ketetapan MPR pengunci dari seluruh Ketetapan MPRS dan MPR. Di masa mendatang MPR tidak lagi berwenang mengeluarkan garis-garis besar daripada haluan negara dalam bentuk ketetapan MPR sebagaimana masa lalu dikarenakan perubahan sistem ketata negaraan dimana MPR hanya menjadi lembaga negara yang sejajar dengan lembaga negara lainnya dan bukan lembaga tertinggi negara lagi. Untuk menghindari kekosongan hukum akibat perubahan sistem ketata negaraan ini maka Aturan Tambahan Pasal I memerintahkan MPR untuk melakukan peninjauan yang digunakan sebagai payung hukum status seluruh Ketetapan MPRS dan MPR. 20

Selain Ketetapan Majelis Permusyawaratan Rakyat Nomor I/MPR/2003, MPR juga mengeluarkan ketetapan terakhir MPR yaitu Kete-

20 Loc.cit tapan Majelis Permusyawaratan Rakyat Nomor II/ MPR/ 2003 tentang Perubahan Kelima atas Ketetapan Majelis Permusyawaratan Rakyat Republik Indonesia Nomor II/MPR/ 1999 tentang Peraturan Tata Tertib Majelis Permusyawaratan Rakyat Republik Indonesia yang juga hanya berlaku sampai dengan ditetapkannya Peraturan Tata Tertib oleh Majelis Permusyawaratan Rakyat Republik Indonesia hasil Pemilihan Umum 2004. Ketetapan MPR yang terakhir kalinya ini juga ditetapkan di J akarta pada hari yang sama yaitu tanggal 7 Agustus 2003.

\section{TAP MPR sebagai Dasar Penyusunan Program Legislasi Nasional}

Program Legislasi Nasional yang selanjutnya disebut Prolegnas adalah instrumen perencanaan program pembentukan Undang-undang yang disusun secara terencana, terpadu, dan sistematis. Dalam pasal 16 Undang-Undang Nomor 12 Tahun 2011 disebutkan bahwa Perencanaan penyusunan Undang-undang dilakukan dalam Prolegnas. Sedangkan dalam Pasal 17 ditegaskan tentang Prolegnas sebagaimana dimaksud dalam Pasal 16 merupakan skala prioritas program pembentukan Undang-Undang dalam rangka mewujudkan sistem hukum nasional. Selanjutnya pada Pasal 18 disebutkan bahwa dalam penyusunan Prolegnas sebagaimana dimaksud dalam Pasal 16, penyusunan daftar Rancangan Undang-Undang didasarkan atas: Perintah UUD 1945; Perintah Ketetapan Majelis Permusyawaratan Rakyat; Perintah Undang-undang lainnya; Sistem perencanaan pembangunan nasional; Rencana pembangunan jangka panjang nasional; Rencana pembangunan jangka menengah; Rencana kerja pemerintah dan rencana strategis DPR; dan Aspirasi dan kebutuhan hukum masyarakat.

Maksud dari kata-kata "Perintah Ketetapan Majelis Permusyawaratan Rakyat" adalah Ketetapan Majelis Permusyawaratan Rakyat Sementara dan Ketetapan Majelis Permusyawaratan Rakyat yang masih berlaku sebagaimana dimaksud dalam Pasal 2 dan Pasal $4 \mathrm{Ke}$ tetapan Majelis Permusyawaratan Rakyat Republik Indonesia Nomor: I/MPR/2003 tentang Peninjauan terhadap Materi dan Status Hukum 
Ketetapan Majelis Permusyawaratan Rakyat Sementara dan Ketetapan Majelis Permusyawaratan Rakyat Tahun 1960 sampai dengan Tahun 2002, tanggal 7 Agustus 2003. (Penjelasan Pasal 18 huruf B) Selain tiga hal di atas, ada persoalan lain yang menarik untuk dikritisi dalam kaitannya dengan kedudukan TAP MPR setelah berlakunya Undang-Undang Nomor 12 Tahun 2011 Tentang Pembentukan Peraturan Perundang-undangan, yang dijelaskan pada bagian di bawah ini.

\section{Kewenangan MPR dalam Membuat Peraturan Perundangan Selain TAP MPR}

Adanya jenis peraturan perundang-undangan yang lain selain yang telah ditetapkan dalam Pasal 7 ayat (1) Undang-undang Nomor 12 Tahun 2011 dapat diketahui dari rumusan Pasal 8 undang-undang tersebut. Pasal delapan menentukan 2 hal, yaitu: ${ }^{21}$ pertama, jenis Peraturan Perundang-undangan selain sebagaimana dimaksud dalam Pasal 7 ayat (1) mencakup peraturan yang ditetapkan oleh Maj elis Permusyawaratan Rakyat, Dewan Perwakilan Rakyat, Dewan Perwakilan Daerah, Mahkamah Agung, Mahkamah Konstitusi, Badan Pemeriksa Keuangan, Komisi Yudisial, Bank Indonesia, Menteri, badan, lembaga, atau komisi yang setingkat yang dibentuk dengan Undang-undang atau Pemerintah atas perintah Undang-Undang, Dewan Perwakilan Rakyat Daerah Provinsi, Gubernur, Dewan Perwakilan Rakyat Daerah Kabupaten/ Kota, Bupati/ Walikota, Kepala Desa atau yang setingkat; dan kedua, Peraturan Perundang-undangan sebagaimana dimaksud pada ayat (1) diakui keberadaannya dan mempunyai kekuatan hukum mengikat sepanjang diperintahkan oleh Peraturan Perundang-undangan yang lebih tinggi atau dibentuk berdasarkan kewenangan.

Ketentuan di atas menimbulkan pertanyaan akademik, khususnya tentang apa maksud dari rumusan Pasal 8 tersebut. Melalui pasal itu dapat diketahui bahwa peraturan yang ditetap-

21 Delfina Gusman, "Problematika Pembentukan Peraturan Perundang-undangan di Indonesia", J urnal Yustisia, Vol. 1 No. $1 \mathrm{~J}$ anuari-J uni 2012, Padang: Fakultas Hukum Universitas Andalas Padang, hlm. 10 kan oleh Majelis Permusyawaratan Rakyat merupakan salah satu jenis peraturan perundangundangan selain sebagaimana dimaksud dalam Pasal 7 ayat (1). Makna literal akan mengarahkan kepada pemahaman bahwa MPR dapat mengeluarkan jenis peraturan perundangundangan yang lain selain TAP MPR. ${ }^{22}$

\section{Implikasi UU No. 12 Tahun 2011 terhadap Pembentukan dan Penyusunan Keputusan Pimpinan Majelis Permusyawaratan Rakyat}

Pernyataan bahwa teknik Penyusunan dan/atau Bentuk yang Diatur dalam UndangUndang Nomor 12 Tahun 2011 berlaku secara mutatis mutandis bagi teknik penyusunan dan/ atau bentuk Keputusan Pimpinan Majelis Permusyawaratan Rakyat dapat diketahui dari rumusan Bab XII Ketentuan Lain-lain. Pasal 97 menyebutkan bahwa teknik penyusunan dan/ atau bentuk yang diatur dalam Undang-Undang ini berlaku secara mutatis mutandis bagi teknik penyusunan dan/atau bentuk Keputusan Presiden, Keputusan Pimpinan Majelis Permusyawaratan Rakyat, Keputusan Pimpinan DPR, Keputusan Pimpinan DPD, Keputusan Ketua Mahkamah Agung, Keputusan Ketua Mahkamah Konstitusi, Keputusan Ketua Komisi Yudisial, Keputusan Kepala Badan Pemeriksa Keuangan, Keputusan Gubernur Bank Indonesia, Keputusan Menteri, Keputusan Kepala Badan, Keputusan Kepala Lembaga, atau Keputusan Ketua Komisi yang setingkat, Keputusan Pimpinan DPRD Provinsi, Keputusan Gubernur, Keputusan Pimpinan DPRD Kabupaten/Kota, Keputusan Bupati/Walikota, Keputusan Kepala Desa atau yang setingkat.

Pada penjelasan bagian umum diilustrasikan bahwa Undang-Undang tentang Pembentukan Peraturan Perundang-undangan merupakan pelaksanaan dari perintah Pasal 22A UndangUndang Dasar Negara Republik Indonesia Tahun 1945 yang menentukan bahwa ketentuan lebih lanjut mengenai tata cara pembentukan undang-undang diatur lebih lanjut dengan undang-undang. Namun, ruang lingkup materi muatan Undang-Undang ini diperluas tidak saja

22 Loc.cit 
Undang-undang tetapi mencakup pula Peraturan Perundang-undangan lainnya, UUD1945 dan Ketetapan Majelis Permusyawaratan Rakyat.

Undang-undang tentang Pembentukan Peraturan Perundang-undangan didasarkan pada pemikiran bahwa Negara Indonesia adalah negara hukum. Sebagai negara hukum, segala aspek kehidupan dalam bidang kemasyarakatan, kebangsaan, dan kenegaraan termasuk pemerintahan harus berdasarkan atas hukum yang sesuai dengan sistem hukum nasional. Sistem hukum nasional merupakan hukum yang berlaku di Indonesia dengan semua elemennya yang saling menunjang satu dengan yang lain dalam rangka mengantisipasi dan mengatasi permasalahan yang timbul dalam kehidupan bermasyarakat, berbangsa, dan bernegara yang berdasarkan Pancasila dan UUD 1945. ${ }^{23}$

Undang-undang ini merupakan penyempurnaan terhadap kelemahan-kelemahan daIam UU No. 10 Tahun 2004, yaitu: ${ }^{24}$ pertama, materi dari Undang-Undang Nomor 10 Tahun 2004 banyak yang menimbulkan kerancuan atau multitafsir sehingga tidak memberikan suatu kepastian hukum; kedua, teknik penulisan rumusan banyak yang tidak konsisten; ketiga, terdapat materi baru yang perlu diatur sesuai dengan perkembangan atau kebutuhan hukum dalam Pembentukan Peraturan Perundang-undangan; dan keempat, penguraian materi sesuai dengan yang diatur dalam tiap bab sesuai dengan sistematika.

Sebagai penyempurnaan terhadap Undang-undang sebelumnya, terdapat materi muatan baru yang ditambahkan dalam UndangUndang ini, yaitu: pertama, penambahan Ketetapan Majelis Permusyawaratan Rakyat sebagai salah satu jenis Peraturan Perundangundangan dan hierarkinya ditempatkan setelah UUD 1945; kedua, perluasan cakupan perencanaan Peraturan Perundang-undangan yang tidak hanya untuk Prolegnas dan Prolegda melainkan juga perencanaan Peraturan Pemerintah, Peraturan Presiden, dan Peraturan Perundang-undangan lainnya; ketiga, pengaturan mekanisme pembahasan Rancangan Undang-un-

23 Ibid

24 Yuliandri, op.cit, hlm. 58 dang tentang Pencabutan Peraturan Pemerintah Pengganti Undang-undang; keempat, pengaturan Naskah Akademik sebagai suatu persyaratan dalam penyusunan Rancangan UndangUndang atau Rancangan Peraturan Daerah Provinsi dan Rancangan Peraturan Daerah Kabupaten/Kota; kelima, pengaturan mengenai keikutsertaan Perancang Peraturan Perundang undangan, peneliti, dan tenaga ahli dalam tahapan Pembentukan Peraturan Perundang-undangan; dan keenam, penambahan teknik penyusunan Naskah Akademik dalam Lampiran I Undang-Undang ini.

Masih diakuinya keberadaan MPR, serta terdapat beberapa kewenangan strategis yang dimiliki MPR, meski terjadi pada waktu-waktu tertentu saja, TAP MPR masih diperlukan keberadaannya dalam hierarki peraturan perundangundangan. TAP MPR yang ke depannya dapat timbul ialah TAP MPR yang berisi mengenai penetapan UUD, pelantikan Presiden dan wakilnya, serta memilih Presiden dan wakilnya dalam hal terjadi kekosongan. Mengenai TAP MPR yang menetapkan gari-garis besar haluan negara, tidaklah dimungkinkan keberadaannya, hal ini dikarenakan UUD tidaklah memberikan kewenangan itu kepada MPR lagi (dialihkan kepada Presiden), pengaturan sistem perencanaan pembangunan nasional diatur dalam UndangUndang No. 25 Tahun 2004. ${ }^{25}$

Berdasarkan hierarki norma hukum negara (die Theorie vom Stufenordnung der Rechtsnormen) Hans Nawiasky, TAP MPR merupakan staatgrundgesetz atau aturan pokok negara yang setingkat dengan Batang Tubuh UUD/ Konstitusi yang merupakan staatsverfassung atau aturan dasar negara. Akan tetapi, perlu diingat pula teori Pengikatan Diri (Selbtsbindungtheorie) dari George J ellinek. Secara teori MPR memiliki kualitas utama sebagai Konstituante (menetapkan UUD), setelah itu MPR mengikatkan diri pada UUD yang ia bentuk tersebut, dan selanjutnya berdasarkan UUD tersebut, MPR menciptakan TAP MPR. Oleh karena-

25 Dwi Putra Nugraha, TAP MPR dan Peraturan Lainnya dalam Hierarki Peraturan Perundang-Undangan, http:// ahok. org/ berita/ pemikiran/ tap-mpr-danperaturan-lainnya-dalam-hierarki-peraturan-perundangundangan/. 
nya, TAP MPR ini diletakkan satu tingkat dari UUD/ Konstitusi. Akan tetapi pilihan yang paling bijak, UUD dan TAP MPR sebagai aturan dasar negara/ aturan pokok negara tidaklah dimasukkan dalam hierarki karena dengan dimasukkannya aturan dasar negara/aturan pokok negara dalam suatu tata susunan/hierarki peraturan perundang-undangan (wetgeving) tersebut membawa dampak mengartikecilkan aturan dasar negara/ aturan pokok negara yang dimiliki oleh Indonesia. ${ }^{26}$

Perdebatan kedudukan atau dimasukkannya kembali TAP MPR dalam hierarki peraturan perundang-undangan akan terus terjadi dan akan sulit menemukan titik temunya. Penulis berpendapat, tidak perlu mempermasalahkan hal tersebut, yang paling penting adalah bagaimana caranya melaksanakan negara hukum yang demokratis sesuai dengan asas-asas/prinsip negara hukum serta bagaimana melahirkan suatu aturan hukum yang responsif seperti yang dikemukakan oleh Todung Mulya Lubis, bahwa masalah kita saat ini adalah hukum kita belum berkarakter responsif/ otonom karena demokrasi kita masih berada ditataran demokrasi prosedural, belum demokrasi substantif. Jadi idealnya kedepan bukan bagaimana cara mensterilkan hukum dari politik, melainkan bagaimana membangun konfigurasi politik demokratis yang substantif, bukan hanya prosedural yang formal. ${ }^{27}$

Maka jelaslah, bukan jenis produk hukumnya yang harus dipermasalahkan kedudukannya, melainkan hasil produk hukum tersebut bagaimana sifatnya, apakah bertentangan dengan hak asasi manusia, apakah bertentangan dengan keadilan masyarakat dan lain sebagainya. Mengutip pendapat Schelmena, ada 4 unsur utama suatu negara hukum yang baik, yaitu: ${ }^{28}$ asas kepastian hukum; asas persamaan;

26 Ibid.

27 Todung Mulya Lubis, "Menuju Hukum Responsif: Indonesia Di Persimpangan Jalan", J urnal Konstitusi Vol. 1 No. 1 November 2010, Padang: Fak. Hukum Univ. Andalas Padang, hlm. 40

28 Mirza Alfath, "Relasi Kekuasaan dan Hukum Dalam Kasus Kejahatan Terhadap Keamanan Negara, Kajian Putusan No.78/ Pid B/2003/ PN.LSK", Jurnal Yudisial Vol. IV No. 2 Agustus 2011, Jakarta: Komisi Yudisial, hlm. 162-163 asas demokrasi; dan asas pemerintahan untuk rakyat.

\section{Penutup}

Kedudukan TAP MPR setelah berlakunya undang-undang Nomor 12 tahun 2011 tentang pembentukan peraturan perundang-undangan adalah bahwa TAP MPR merupakan salah satu jenis peraturan perundangan-undangan yang berlakunya di Indonesia. Secara hirarki TAP MPR berada di bawah Undang-Undang Dasar Negara Republik Indonesia Tahun 1945. Kedudukan TAP MPR dimaksud adalah TAP MPR sebagaimana yang dimaksud oleh Pasal 2 dan 4 TAP MPR Nomor 1 Tahun 2003, sedangkan TAP MPR yang diluar pasal tersebut dinyatakan tidak berlaku. TAP MPR juga menjadi salah satu da-sar pembentukan Program Legislasi Nasional yakni dengan adanya perintah dari TAP MPR tersebut.

Penelitian ini masih bersifat tinjauan awal tentang kedudukan TAP MPR sebagai sikap proaktif dalam dunia akademik dengan telah berlakunya UU Nomor 12 tahun 2011 tentang Pembentukan Peraturan Perundang-undangan. Oleh karena itu, disarankan agar ada penelitian lanjutan sehingga dapat lebih mengungkapkan eksistensi TAP MPR di Indonesia secara detail berdasarkan peraturan-perundangan yang berlaku. Serta dapat juga ditinjau lebih jauh tentang keberadaan TAP MPR ke depan dalam kaitannya dengan tugas dan kewenangan MPR yang ditetapkan oleh Undang-Undang Dasar Negara Republik Indonesia Tahun 1945.

\section{Daftar Pustaka}

Abdullah, Abdul Gani. "Pengantar Memahami Undang-Undang Tentang Pembentukan Peraturan Perundang-undangan". J urnal legislasi Indonesia J akarta, 2004;

Alfath, Mirza, "Relasi Kekuasaan dan Hukum dalam Kasus Kejahatan Terhadap Keamanan Negara, Kajian Putusan No.78/ Pid B/ 2003/ PN.LSK", Jurnal Yudisial Vol. IV No. 2 Agustus 2011. Jakarta: Komisi Yudisial;

Asshiddiqie, Jimly. Gagasan Negara Hukum Indonesia. http://jimly.com/ makalah/ namafile/ 57/ Konsep_Negara_Hukum_Ind; 
Attamimi, A. Hamid. 1990. Peranan Keputusan Presiden Republik Indonesia dalam Penyelenggaraan Pemerintahan Negara: Suatu Studi Analisis Mengenai Keputusan Presiden yang Berfungsi Pengaturan dalam kurun waktu Pelita I - Pelita IV. Disertasi untuk memperoleh Gelar Doktor dalam IImu Hukum pada Fakultas Pascasarjana Universitas Indonesia, J akarta

Aziz, Machmud. "Pengujian Peraturan Perundang-undangan dalam Sistem Perundangundangan Indonesia", J urnal Konstitusi Vol. 7 No. 5 Oktober 2010. Padang: Fak. Hukum Univ. Andalas;

Djafar, Wahyudi. "Menegaskan Kembali Komitmen Negara Hukum: Sebuah Catatan Atas Kecenderungan Defisit Negara Hukum di Indonesia". J urnal Konstitusi Vol. 7 No. 5 Oktober 2010. Padang: Fak. Hukum Univ. Andalas;

Gunawan, Yordan dan Alex Adi Iskandar- "Implementasi Kedaulatan Rakyat Dalam Sistem Ketatanegaraan Pasca Amandemen UUD 1945" - J urnal Konstitusi Vol. 3 No. 1 J uni 2010. Padang: Fak. Hukum Univ. Andalas;

Fatmawati, "Perlindungan Hak Atas Kebebasan Beragama dan Beribadah Dalam Negara Hukum Indonesia", J urnal Konstitusi Vol. 8 No. 4 Agustus 2011. Padang: Fak. Hukum Univ. Andalas;

Gusman, Delfina- "Tinjauan Materi dan Status Hukum Ketetapan MPRS/ MPR Berdasarkan Ketetapan RI Nomor I/ MPR/2003". J urnal Ilmiah Normative. Padang: Univ. Taman Siswa Padang Padang, 2008;

, "Independensi Bank Indonesia Sebagai Bank Sentral Dalam Sistem Ketatane- garaan Indonesia". Jurnal Normative. Padang: Universitas Taman Siswa Padang, 2010;

"Politik Hukum dan Modifikasi Hukum dalam Pembentukan Peraturan Perundang-undangan Nasional". Jurnal IImiah TAMBUA, Solok: Univ. Mahaputra Muhammad Yamin Solok, 2011;

-.---.-. “Problematika Pembentukan Peraturan Perundang-undangan di Indonesia". Jurnal Yustisia, Padang: Fakultas Hukum Universitas Andalas Padang, 2012;

J unaidi, Veri. "Pelanggaran Sistematis, Terstruktur dan Masif: Suatu Sebab Pembatalan Kehendak Rakyat dalam Pemilihan Kepala Daerah Tahun 2010". J urnal Konstitusi Vol. 7 No. 5 Oktober 2010. Padang: Fak. Hukum Univ. Andalas;

Kusuma, R.M.A.B., " "Sistem Pemerintahan Sebelum dan Sesudah Amandemen". Jurnal Konstitusi Vol. 1 No. 1 November 2010. Padang: Fak. Hukum Univ. Andalas;

Lubis, Todung Mulya. "Menuju Hukum Responsif: Indonesia Di Persimpangan Jalan". Jurnal Konstitusi Vol. 1 No. 1 November 2010. Padang: Fak. Hukum Univ. Andalas;

Nugraha, Dwi Putra. TAP MPR dan Peraturan Lainnya dalam Hierarki Peraturan Perundang-Undangan, http://ahok.org/ berita/ pemikiran/tap-mpr-dan-peraturan-lainnya-dalam-hierarki-peraturanperundang-undangan/ .

Yuliandri. 2007. Asas-Asas Pembentukan Peraturan Perundang-undangan yang Baik dalam Rangka Pembuatan Undang-Undang Berkelanjutan, Surabaya: Universitas Airlangga. 